\title{
Final Semester Assessment (PAS) in The Covid-19 Era Based on the Integrity of Teachers, Students, and Parents
}

\author{
Eva Dwi Kumala Sari ${ }^{*}$, Santi Lisnawati ${ }^{2}$, Winti Ananthia ${ }^{3}$ \\ ${ }^{1}$ Islamic education, STIT Al- Marhalah Al-'Ulya, Bekasi, Indonesia \\ 2 Islamic education, Universitas Ibn Khaldun, Bogor, Indonesia \\ ${ }^{3}$ Primary Teacher Education, Universitas Pendidikan Indonesia Kampus Cibiru, Bandung, Indonesia \\ *e-mail: eva@almarhalah.ac.id
}

\begin{abstract}
This study aims to analyze the integrity of teachers, students, and parents in the Final Semester Assessment (PAS) conducted in the COVID-19 pandemic. PAS is the final process of measuring the achievement of student learning outcomes as one of the considerations for successful knowledge acquisition in one semester. Therefore, it is necessary to have high integrity in its implementation to describe the actual learning achievement of students. This study employed a descriptive quantitative method involving teachers $(n=109)$, students $(n=725)$ and parents $(n=846)$ from various public and private elementary schools in Bekasi. Furthermore, survey was conducted using google form for data collection, where respondents were asked to input several statements related to the integrity of teachers, parents and students in the PAS. The data from the documents or questionnaires were analyzed using descriptive-exploratory method to draw reflective conclusions. The results showed (1) the integrity of teachers in PAS included in the low category was $15.60 \%$, the medium was $69.72 \%$, and high was $14.68 \%$. (2) the integrity of students which was categorized as low was $10.89 \%$, medium was $81.24 \%$, and high was $7.86 \%$. (3) the integrity of parents categorized as low was $15.60 \%$, medium was $72.34 \%$, and the high was $12.05 \%$. It was concluded that teachers, students, and parents who have high integrity in PAS were far-outnumbered by those in the low or medium category. Therefore, integrity in the school and family environment should be continuously improved.
\end{abstract}

Keywords: Final Semester Assessment, Teacher Integrity, Student Integrity and Parent Integrity

\section{Introduction}

The COVID-19 outbreak caused tremendous challenges in the educational world, in which physical classes were changed to online (Fauzi et al., 2020; Gouëdard et al., 2020). This is in accordance with the Indonesian Minister of Education and Culture decree through Circular no. 4 of 2020 concerning the implementation of teaching and learning process to be carried out from home in order to curb the spread (Abidah et al., 2020; Giatman et al., 2020; Sri et al., 2020). Based on this decree, Distance Education is currently the ideal method to break the spread of the virus (Rasmitadila et al., 2020). Since the implementation of Distance Education, PAS is not allowed to be carried out in schools but online and take-home (Nasr, 2020; Rahim \& Fuad, 2020). This assessment is important to be considered as a determinant of learning success (Allen et al., 2021; Mardapi, 2013; Sari \& Mahmudi, 2019). The decree of the Minister of Education and Culture becomes the reference for schools in conducting the assessment (Sari, 2018; Sari et al., 2017; Sari \& Mahmudi, 2019).

Currently, Final Semester Assessments (PAS) carried out in schools use the online method. However, there are schools providing test sheets that are allowed to be taken home and returned within a stipulated time. This assessment certainly experience many problems (Reedy et al., 2021). The PAS implementation during the pandemic conditions needs to be addressed with various preparations by parents, teachers, and the school (Lancaster \& Cotarlan, 2021). Furthermore, integrity is needed to be considered in the context of the PAS success (Benson et al., 2019; Halaweh, 2020). Integrity is honesty, truth, consistency, and responsibility (Sarjana \& Khayati, 2017). In fact, integrity is proven when one's personality reflects honesty, loyalty, responsibility, trust, and avoidance of lies/pretense, or when such a

\footnotetext{
*Corresponding author.
}

Received February 02, 2021; Accepted October 18, 2021; Available online December 25, 2021 This is an open access article under the CC BY-SA license. Copyright $(2021$ by Author. Published by Universitas Pendidikan Ganesha 
person can be a role model for others (Redjeki D.P, 2013; Sari \& Falani, 2021). Furthermore, it is an emphasis on moral consistency, personal wholeness, or honesty (Jacobs, 2004), and it is always associated with individual honesty (Sari, 2019; Yulk G.A \& Van Fleet, 1992). Integrity for oneself is described as being honest, courageous, consistent in principles, and having good character. Meanwhile, integrity for others is shown by respect, compassion, and care, as well as being able to adapt to the environment (Stoesz et al., 2019; Widyarini et al., 2019).

Integrity is essential in the PAS because it is the final process of measuring the achievement of student learning outcomes as one of the considerations for class advancement (Mardapi, 2013; Sari et al., 2017; Sari \& Mahmudi, 2019). Furthermore, there is need for integrity by teachers, students, and parents in the evaluation due to a lot of academic dishonesty in implementing online and take-home-based assessments (Gamage et al., 2020; Haynie, 2003). The challenges of Remote Assessments, it was shown that there was academic dishonesty committed by students in remote evaluation due to lack of preparation (Fontaine et al., 2020). Furthermore, Haynie, (2003) showed classroom assessment is more effective than take-home (Guangul et al., 2020). This was supported by statement that take-home and open-book assessments are prone to academic dishonesty, which is detrimental to students (Stoesz et al., 2019). This shows integrity is important to be considered in the online PAS.

The implementation of the online assessment has to uphold integrity as a character that is always cultivated among students (Stoesz et al., 2019). Therefore, in online PAS activities and completing the take-home questions, parents are involved in monitoring the exam implementation in their respective homes. The parent's involvement in this supervision is mainly in the form of support and care even though it is limited to delivering special advice (Khilmiyah et al., 2015) as well as accompanying their children who are working on the PAS questions (Aswadi \& Kasmilawati, 2020; Hikam, 2020). Parent's assistance when implementing online assessment at home may not be the same as mentoring by supervising teachers during exams at school. Every parent would want good results from their child's exam. Therefore, they will engage actively to strive for their children's best test results, with different forms of facilities and home environment conditions especially in certain distinct situations for each family. Furthermore, in this online assessment activity, the principle of honesty in working on questions is also a part that needs attention from parents. The great attention of parents in assisting students will improve learning achievement and good character for their children (Hikam, 2020).

The reality is that there are students' who do not honestly solve the PAS questions, but commit various cheating or ask their parents for help. This happens because many parents are worried about the low scores that will be achieved, hence they assist in doing the PAS. Besides parents, teachers also become a very important dilemma in determining the PAS, because they feel uncertain about the honesty of parents and students (Rasmitadila et al., 2020; Vučković et al., 2020). Based on these conditions, it is interesting to conduct a study on the PAS during the COVID-19 pandemic in terms of the teacher's, student's and parent's integrity. Therefore, this study aims to determine the implementation of the final semester assessment (PAS) in terms of teachers', students', and parents' integrity during the COVID-19 pandemic.

\section{Method}

This study used descriptive quantitative methods (Creswell, 2016). Data collection was carried out by questionnaire (Sugiyono, 2012) using a google form, where respondents were asked to fill in several statements related to the integrity of teachers, parents and students in the PAS. This was carried out by distributing three instrument links, which was filled by teachers, parents and students. Each link contains 10 statements of Integrity. The participants were students, teachers and parents of public elementary school (SDN) students and integrated Islamic elementary schools in Bekasi. The participants were teachers $(\mathrm{n}=$ 109), students $(n=725)$ and parents $(n=846)$ from various public and private elementary 
schools in the location. The data analysis used descriptive-exploratory method (Sugiyono, 2016), and contents of the document or questionnaire data were analyzed to reflectively draw conclusions. In addition, this study used percentages and comparisons for quantitative data analysis (Rustam et al., 2018).

\section{Result and Discussion}

\section{Results}

\section{Teacher Integrity}

Categorizing teachers' answers regarding the PAS integrity was conducted to determine how the assessment was executed during the pandemic. This evaluation was manually carried out online at home. Hence, question sheets were taken home and answers were expected to be returned. This is related to "how is the teacher's integrity in conducting PAS? The answers given by participants can be seen in Table 1.

Table 1. The Meaning of Teacher Integrity in the PAS Assessment

\begin{tabular}{lc}
\hline \multicolumn{1}{c}{ Statement } & Frequency \\
\hline I will assess the student's PAS according to the student's daily life & $84.77 \%$ \\
PAS assessments were carried out according to the results of the & $84.40 \%$ \\
students' answers & $61.83 \%$ \\
I did the PAS assessment in the covid-19 era based on the scores & \\
from the previous class & $62.94 \%$ \\
I believe that student scores for homework assignments in the Covid- & $73.03 \%$ \\
I era are the result of their own work. & $69.91 \%$ \\
I am worried that student work at home is the parents' work. & $93.76 \%$ \\
I will collect student books during PAS exams & $70.83 \%$ \\
I have active communication with the parents & $93.21 \%$ \\
I did an assessment to see the students' daily activities and the & $46.61 \%$ \\
Punctuality of doing or collecting PAS & \\
I realized that many students are less capable of doing PAS, therefore & \\
I gave grades by guessing &
\end{tabular}

Table 1 illustrates each instrument percentage given to 109 teachers, which showed most of the teachers made PAS. According to the tenth statement, $46.61 \%$ were uncertain whether the results are purely students' abilities or with parent's help. Therefore, their conclusion was conducted by guessing. This is consistent with the statement contained in the fifth, that $73.03 \%$ are concerned the test results were their parents' work. Furthermore, $61.83 \%$ conducted an assessment based on the previous class, hence this became the basic benchmark for assessing class results at this time. Based on the table, an assessment of teacher integrity was carried out using a level categorization model by placing teachers in 3 (three) groups, namely, understanding of high, medium and low integrity by utilizing theoretical average benchmarks $(\mu)$ and standard deviation theoretical (ó), with details;

$X<(\mu-10) \quad:$ : Teachers have low assessment integrity

$(\mu-10 ́) \leq X<(\mu+10$ ) : Teachers have medium assessment integrity

$X \geq(\mu+10$ ) : Teachers have high assessment integrity

The integrity instrument consists of 10 items with the lowest and highest scores as 10,50 respectively. Therefore, area of the distribution distance became $50-10=40$, hence large ó (standard deviation) $=5,327$ and $\mu$ (theoretical average) $=37.06$. In order to facilitate the interpretation of the teacher assessment integrity using this developed instrument, the range of the assessment was made as shown in Table 2; 
Table 2. Teacher integrity assessment ranges

\begin{tabular}{clc}
\hline $\begin{array}{c}\text { Score and } \\
\text { Assessment Range }\end{array}$ & Interpretation and Assessment Results & Percentage \\
\hline$X<31.733(\mu-0))$ & Teachers have Low Integrity assessments & $15.60 \%$ \\
$31.733 \leq X<42.387$ & Teachers have Medium Integrity assessments & $69.72 \%$ \\
$X \geq 42.387$ & Teachers have High Integrity assessments & $14.68 \%$ \\
\hline
\end{tabular}

Based on Table 2, those with high integrity are only $14.68 \%$. This is certainly a concern for decision-makers, both the principal and the education office, to improve integrity among teachers. In case of further cheating by teachers, especially in terms of assessment, this will certainly be detrimental to various parties, one of which is parents because they do not get real results from the progress of their children's learning process. There are also many parties who are disadvantaged by schools and the education office, which will definitely hinder the quality of education in Indonesia.

\section{Student Integrity}

Categorizing students' answer about the PAS integrity during the Covid-19 pandemic was conducted to determine how questions were answered at home. The answers given by participants are shown in Table 3.

Table 3. Students' integrity in answering the PAS questions

\begin{tabular}{|c|c|c|}
\hline No & Statements & Frequency \\
\hline 1 & I asked my parents as a whole in answering PAS questions & $36.94 \%$ \\
\hline 2 & $\begin{array}{l}\text { I only asked questions that I did not know in answering the PAS } \\
\text { questions }\end{array}$ & $76.30 \%$ \\
\hline 3 & $\begin{array}{l}\text { I ordered my parents to do the exam questions given by the } \\
\text { teacher }\end{array}$ & $25.21 \%$ \\
\hline 4 & $\begin{array}{l}\text { I worked independently on the exam questions given by the } \\
\text { teacher. }\end{array}$ & $89.24 \%$ \\
\hline 5 & I studied well for PAS. & $91.64 \%$ \\
\hline 6 & My parents were able to motivate me to study hard. & $95.75 \%$ \\
\hline 7 & I am responsible for completing PAS on time. & $93.60 \%$ \\
\hline 8 & $\begin{array}{l}\text { I was given the freedom to study and try to fulfill good learning } \\
\text { achievements. }\end{array}$ & $95.67 \%$ \\
\hline 9 & My parents reminded me to study when I was lazy. & $96.52 \%$ \\
\hline 10 & Parents helped to explain the difficult lessons. & $93.27 \%$ \\
\hline
\end{tabular}

Table 3 describes the student's integrity in completing the PAS. The percentage of the instruments answers given to 725 students can be described that in answering thequestions, they were assisted by their parents. This is shown in the first statement that $36.94 \%$ asked their parents for help in answering the questions. There were $76.30 \%$ students who asked their parents only questions they could not answer, in fact, $25.21 \%$ deliberately ordered their parents to answer the questions. However, when viewed from other statements, students already have good integrity, especially in terms of responsibility for completing on time, according to the 7th statement. Based on the table, an assessment on the integrity of students was carried out using the level categorization model by placing them in 3 (three) levels, namely high, medium, and low integrity using the benchmarks of theoretical average $(\mu)$ and theoretical standard deviation ( ó), with the following details;

$$
\begin{array}{ll}
X<(\mu-10 ́) & : \text { Students have Low Integrity } \\
(\mu-10 \text { - }) \leq X<(\mu+10) & : \text { Students have Medium Integrity } \\
X \geq(\mu+10) & : \text { Students have High Integrity }
\end{array}
$$


The integrity instrument consists of 10 items with the lowest score $=10$ and the highest $=50$. Therefore, the area of the distribution distance becomes $50-10=40$, hence the size of ó (standard deviation) $=3.562$ and $\mu$ (theoretical average) $=39.71$. In order to facilitate the results interpretation in student assessment integrity using this developed instrument, a range assessment was made according to Table 4;

Table 4. Range of student integrity assessment in working on PAS

\begin{tabular}{ccc}
\hline $\begin{array}{c}\text { Score and Assessment } \\
\text { Range }\end{array}$ & $\begin{array}{c}\text { Interpretation and Assessment } \\
\text { Results }\end{array}$ & Percentage \\
\hline$X<36.148(\mu-0 ́)$ & students have Low Integrity & $10.89 \%$ \\
\hline $36.148 \leq X<43.272$ & students have Medium Integrity & $81.24 \%$ \\
\hline$X \geq 43.272$ & students have High Integrity & $7.86 \%$ \\
\hline
\end{tabular}

The table shows that of the 725 students who filled out the questionnaire, there were still very few who had high integrity. Only $7.86 \%$ had honesty in working on the questions. Parent Integrity. Categorizing the parents respondents' answers about the integrity of PAS assistance in the Covid-19 pandemic was carried out to determine how they provided help to their children by answering the questions at home. The integrity addressed to parents is "how is their integrity in assisting their children when working on PAS questions?" The answers given by the participants can be seen in Table 5 .

Table 5. The integrity of parents in assisting children in working on PAS questions

\begin{tabular}{lll}
\hline No & Statement & Frequency \\
\hline 1 & I will let my child do the exam questions independently. & $91.85 \%$ \\
2 & $\begin{array}{l}\text { I will help my child in answering PAS questions because he is worried } \\
\text { about the scores he will get. }\end{array}$ & $41.95 \%$ \\
3 & I instill honesty in my children during PAS & $95.27 \%$ \\
4 & The score my child gets is not important. & $53.74 \%$ \\
5 & $\begin{array}{l}\text { Environmental conditions at home support children's learning } \\
\text { concentration. }\end{array}$ & $81.71 \%$ \\
6 & I believe in the child's ability to do PAS. & $90.85 \%$ \\
7 & I help my child do PAS because my child plays a lot. & $36.18 \%$ \\
8 & I realized my child's inability to do PAS, hence I helped. & $39.93 \%$ \\
9 & I chose to ignore my child's PAS. & $30.26 \%$ \\
10 & I feel disadvantaged when my child's PAS scores are not in & $57.84 \%$ \\
\hline & accordance with his abilities. & \\
\hline
\end{tabular}

Table 5 shows that out of the 846 parents who filled out the questionnaire, many helped their children. This can be seen from the second statement that about $41.95 \%$ helped their children in doing the PAS questions because they were worried about the scores their children will get. Furthermore, $36.18 \%$ answered the questions because their children played more. This condition is certainly very sad to acknowledge because parents who were supposed to guide their children in learning had decided to work on questions that should be answered by their children. Moreover, 39.93\% parents who were fully aware of their children's shortcomings answered the questions. Based on the table, an evaluation on the integrity of parents in conducting assessment was carried out using a level categorization model by placing them in 3 (three) groups, namely high, medium and low integrity using the benchmarks of theoretical average $(\mu)$ and theoretical standard deviation ( ó), with the following details;

$X<(\mu-10$ ) $\quad:$ Students have low integrity

$(\mu-10) \leq X<(\mu+10$ ) $\quad$ : Students have medium integrity

$X \geq(\mu+10) \quad$ : Students have high integrity 
The parent assessment integrity instrument consists of 10 items with the lowest score $=10$ and the highest $=50$. Therefore, the area of the distribution distance becomes $50-10=$ 40 , hence the size of ó (standard deviation) $=4.259$ and $\mu$ (theoretical average) $=30.98$. In order to facilitate the interpretation of the results in parent assessment integrity using this developed instrument, a range of assessment was made as shown in Table 6; the table shows $12.05 \%$ of the 846 parents are categorized as having high integrity.

Table 6. Range of parent integrity assessment in assisting their children in doing PAS

\begin{tabular}{lll}
\hline $\begin{array}{l}\text { Score and Assessment } \\
\text { Range }\end{array}$ & $\begin{array}{l}\text { Interpretation and Assessment } \\
\text { Results }\end{array}$ & Percentage \\
\hline$X<26.721(\mu-0))$ & Parents have Low Integrity & $15.60 \%$ \\
$26.721 \leq X<35.239$ & Parents have Medium Integrity & $72.34 \%$ \\
$X \geq 35.239$ & Parents have High Integrity & $12.05 \%$ \\
\hline
\end{tabular}

\section{Discussion}

The results showed many irregularities have occurred in the implementation of PAS in the pandemic pandemic. The PAS conducted during the pandemic are a dilemma for teachers because they are faced with a different situation. Before the pandemic, the assessments were carried out in schools where teachers could directly observe the exam process and believe the results were the actual abilities of the students. During the current pandemic, teachers were worried about taking evaluation in implementing PAS because students worked on the assessment questions at home. Many possibilities have occurred in the implementation, such as academic fraud as well as dishonesty. This is in accordance with several studies conducted in various countries (Guangul et al., 2020; Haynie, 2003; Kearns, 2012) that there is a lot of academic dishonesty when the assessments are carried out online and at home. The reality is that parents who are given the trust by the teachers to supervise and assist their children actually helped them in working on the questions because of worries about the scores their children will get. Moreover, lack of parent's understanding in terms of evaluation causes them to forget the function of the assessment itself. PAS should be expected to describe the results of student's success in the learning process during the pandemic, but this is lost due to the lack of parents' integrity in working on the assessment.

Based on the students' integrity, there are still very few who have high integrity in answering the questions. This is because majority do not understand the importance of honesty in answering questions, although they cannot be blamed because the respondents are elementary school students who in fact really need direction and guidance from both teachers and parents. Teachers are expected to pay special attention and protect students who need guidance because they also work together with adults who are responsible for children (Antonio \& Miguel, 2021; Sari, 2019; Sari et al., 2019). Also, parents play an important role in shaping good character in the pandemic era (Aswadi \& Kasmilawati, 2020; Rahim \& Fuad, 2020). Furthermore, the school can optimize intensive communication between parents and homeroom teachers through the WhatsApp group, zoom, google meet, and cisco Webex (Mishra et al., 2020; Nasr, 2020; Wahyudi et al., 2020). This communication includes information on school activities, monitoring student learning development, supervising the effectiveness of online PAS implementation and its problems, as well as other matters related to the growth of academic abilities and personalities. Parents and homeroom teachers should work together in order to remind and emphasize more about honesty in working on exam questions. In this case, there is a need to work together in the learning process during the Covid-19 pandemic (Rasmitadila et al., 2020). With all these treatments, it is expected that dishonesty of students and parents can be minimized, hence the teacher will obtain maximum results in conducting assessments. The PAS, which should be a measure of student learning success is actually an event to get the best score among parents. Prior to the pandemic, behaviors like cheating in school exams might be minimized because there was supervision from teachers in its implementation (Halaweh, 2020). This is a concern for policymakers to think more about the best way to carry out exams in a 
pandemic era like today. Therefore, many steps should be prepared because the end of the pandemic cannot be ascertained (Haynie, 2003).

The steps that can be prepared in order to minimize dishonesty in the PAS implementation include eliminating multiple choice and fill-in questions, better emphasis on procedures, steps, and principles of the approach used in problem-solving, randomizing assignments, meaning each student should be given a different task group (Scott, 2017; Toledo \& Orús, 2021; Wangid et al., 2017), giving rubric assessments (Miknis et al., 2020; Sari et al., 2017; Sari \& Mahmudi, 2019), avoiding simple calculations. Moreover, to improve integrity, an agreement can be made before questions are taken home for assessment, determine the deadline for collection, and provide opportunities to interact on things students do not understand (Guangul et al., 2020; Haynie, 2003; Kearns, 2012; Rahim \& Fuad, 2020). The test can also be carried out on an application basis to conduct an assessment (Knight \& Drysdale, 2020; Krisnawati, 2017; Setiaji et al., 2021; Wahyudi et al., 2020). Technologybased assessments are also required to provide feedback for student's motivation in order to complete evaluation (MacKay et al., 2019). In fact, some countries still administer exams online, and deal with cheating using software that can monitor the running of the exam from home and supervise the surrounding environment (Halaweh, 2020; Kearns, 2012). The results will become a consideration in implementing PAS in the next semester (Gouëdard et al., 2020; Mishra et al., 2020; UNESCO, 2020). It is expected that there will be thorough preparation in the implementation of assessment carried out online and take-home, therefore the cheating that occurs in the evaluation process can be minimized, and the assessments carried out truly describe the students' abilities. In this study, some limitations have not revealed in-depth the challenges to the online exams implementation and the forms of integrity that are carried out in detail. This limitation is due to the nature of this study in the form of a survey that reveals the general surface occurring in respondents. Therefore, specific and in-depth matters can be examined further in a qualitative manner.

\section{Conclusions and Suggestions}

This study had provided a significant result that there is a lot of academic dishonesty in the implementation of final semester assessments (PAS) which are conducted online and take-home. It was discovered that parents still help their children in completing PAS because they are worried about the grades. Likewise, students often ask their parents for answers when they do not know the correct option, sadly, many children do not care about the PAS because they completely leave it to their parents. The results also showed PAS is not running properly. Therefore, special attention is needed from the school and teachers to enlighten parents and students to always instill honest value in the assessment process. This is because the PAS is an activity carried out to assess learning success and measure student achievement competencies while studying at home during the covid-19 pandemic. Finally, to minimize academic dishonesty, an effort that needs to be implemented is to create a software, which can be used to monitor students during the final semester assessment.

\section{References}

Abidah, A., Hidaayatullaah, H. N., Simamora, R. M., Fehabutar, D., \& Mutakinati, L. (2020). The Impact of Covid-19 to Indonesian Education and Its Relation to the Philosophy of "Merdeka Belajar." Studies in Philosophy of Science and Education, 1(1), 38-49. https://doi.org/10.46627/sipose.v1i1.9.

Allen, R. E., Kannangara, C., \& Carson, J. (2021). True grit: How important is the concept of grit for education? a narrative literature review. International Journal of Educational Psychology, 10(1), 73-87. https://doi.org/10.17583/IJEP.2021.4578.

Antonio, J., \& Miguel, M. (2021). Social Support by Teacher and Motivational Profile of Higher Education Students. 13(1), 9-25. https://doi.org/10.25115/psye.v10i1.2658.

Aswadi, D., \& Kasmilawati, I. (2020). Penanaman Pendidikan Karakter Anak di Sekolah Melalui Gawai di Era Disrupsi. STILISTIKA: Jurnal Bahasa, Sastra, Dan 
Pengajarannya,

$5(1)$

$10-21$.

https://www.stkipbjm.ac.id/mathdidactic/index.php/STI/article/view/1157.

Benson, L., Rodier, K., Enström, R., \& Bocatto, E. (2019). Developing a university-wide academic integrity e-learning tutorial: A Canadian case. International Journal for Educational Integrity, 15(1), 1-23. https://doi.org/10.1007/s40979-019-0045-1.

Creswell, J. W. (2016). Research Design (Pendekatan Metode Kualitatif, Kuantitatif dan Campuran (1st ed.). Pustaka Pelajar.

Fauzi, I., Khusuma, S., \& Hermawan, I. (2020). Teachers' Elementary School in Online Learning of COVID-19 Pandemic Conditions. Jurnal Iqra': Kajian IImu Pendidikan, 5(1), 58-70. https://doi.org/10.25217/ji.v5i1.914.

Fontaine, S., Frenette, E., \& Hébert, M. H. (2020). Exam cheating among Quebec's preservice teachers: the influencing factors. International Journal for Educational Integrity, 16(1), 1-18. https://doi.org/10.1007/s40979-020-00062-6.

Gamage, K. A. A., de Silva, E. K., \& Gunawardhana, N. (2020). Online delivery and assessment during COVID-19: Safeguarding academic integrity. Education Sciences, 10(11), 1-24. https://doi.org/10.3390/educsci10110301.

Giatman, M., Siswati, S., \& Basri, I. Y. (2020). Online Learning Quality Control in the Pandemic Covid-19 Era in Indonesia. Journal of Nonformal Education, 6(2), 168-175. https://journal.unnes.ac.id/nju/index.php/jne.

Gouëdard, P., Pont, B., \& Viennet, R. (2020). Edu/Wkp(2020)12 Directorate For Education And Skills Education Responses To Covid-19: Implementating a Way Forward OECD. www.oecd.org/edu/workingpapers.

Guangul, F. M., Suhail, A. H., Khalit, M. I., \& Khidhir, B. A. (2020). Challenges of remote assessment in higher education in the context of COVID-19: a case study of Middle East College. Educational Assessment, Evaluation and Accountability, 32(4), 519535. https://doi.org/10.1007/s11092-020-09340-w.

Halaweh, M. (2020). Are universities using the right assessment tools during the pandemic and crisis times? Higher Learning Research Communications, 11(0), 1-9. https://doi.org/10.18870/hlrc.v11i0.1184.

Haynie, W. J. (2003). Effects of Take-Home Tests and Study Questions on Retention Learning in Technology Education. Journal of Technology Education, 14(2), 6-18. http://search.ebscohost.com/login.aspx?direct=true\&db=eric\&AN=EJ667398\&site=eh ost-live\&scope=site.

Hikam, F. F. (2020). Peran Keluarga Dalam Pembelajaran Berbasis E-Learning Pada Masa Wabah Covid-19. Jurnal Pendidikan Dan Dakwah, 2(2), 194-203. https://ejournal.stitpn.ac.id/index.php/pandawa/article/view/695.

Jacobs, D. C. (2004). "A Pragmatist Approach to Integrity in Business Ethics." , Journal of Management Inquiry, 13(3), 215-223. https://doi.org/10.1177\%2F1056492604268203.

Kearns, L. (2012). Student Assessment in Online Learning: Challenges and Effective Practices. Jolt.Merlot.Org, $\quad$ 8(3), 198-208. http://jolt.merlot.org/vol8no3/kearns_0912.htm.

Khilmiyah, A., Sumarno, S., \& Zuchdi, D. (2015). Pengembangan Model Penilaian Keterampilan Intrapribadi Dan Antarpribadi Dalam Pendidikan Karakter Di Sekolah Dasar. Jurnal Penelitian Dan Evaluasi Pendidikan, 19(1), 1-12. https://doi.org/10.21831/pep.v19i1.4550.

Knight, G. L., \& Drysdale, T. D. (2020). The future of higher education (HE) hangs on innovating our assessment-but are we ready, willing and able? Higher Education Pedagogies, 5(1), 57-60. https://doi.org/10.1080/23752696.2020.1771610.

Krisnawati, C. (2017). Upaya Meningkatkan Integritas dan Fokus Dalam Penilaian Pembelajaran dengan Penggunaan Aplikasi E-XAM CARAKA. Ideguru: Jurnal Karya IImiah Guru, 2(1), 63-70. https://jurnaldikpora.jogjaprov.go.id/index.php/jurnalideguru/article/view/26. 
Lancaster, T., \& Cotarlan, C. (2021). Contract cheating by STEM students through a file sharing website: a Covid-19 pandemic perspective. International Journal for Educational Integrity, 17(1), 1-16. https://doi.org/10.1007/s40979-021-00070-0.

MacKay, J. R. D., Hughes, K., Marzetti, H., Lent, N., \& Rhind, S. M. (2019). Using National Student Survey (NSS) qualitative data and social identity theory to explore students' experiences of assessment and feedback. Higher Education Pedagogies, 4(1), 315330. https://doi.org/10.1080/23752696.2019.1601500.

Mardapi, D. (2013). Evaluasi Penerapan Ujian Akhir Sekolah Dasar Berbasis Standar Nasional. Jurnal Penelitian Dan Evaluasi Pendidikan, 13(2), 227-245. https://journal.uny.ac.id/index.php/jpep/article/view/1411.

Miknis, M., Davies, R., \& Johnson, C. S. (2020). Using rubrics to improve the assessment lifecycle: a case study. Higher Education Pedagogies, 5(1), 200-209. https://doi.org/10.1080/23752696.2020.1816843.

Mishra, L., Gupta, T., \& Shree, A. (2020). Online teaching-learning in higher education during lockdown period of COVID-19 pandemic. International Journal of Educational Research Open, 1(June), 100012. https://doi.org/10.1016/j.ijedro.2020.100012.

Nasr, N. (2020). Teachers as Students: Adapting to Online Methods of Instruction and Assessment in the Age of COVID-19. Electronic Journal for Research in Science \& Mathematics Education, 24(2), 168-171. https://ejrsme.icrsme.com/article/view/20338.

Rahim, A., \& Fuad, A. (2020). Guidelines for Online Assessment in Emergency Remote Teaching during the COVID-19 Pandemic. Education in Medicine Journal, 12(2), 5968. https://doi.org/10.21315/eimj2020.12.2.6.

Rasmitadila, Aliyyah, R. R., Rachmadtullah, R., Samsudin, A., Syaodih, E., Nurtanto, M., \& Tambunan, A. R. S. (2020). The perceptions of primary school teachers of online learning during the covid-19 pandemic period: A case study in Indonesia. Journal of Ethnic and Cultural Studies, 7(2), 90-109. https://doi.org/10.29333/ejecs/388.

Redjeki D.P, S. \& Herdiansyah. (2013). Memahami sebuah konsep Integritas. Jurnal STIE Semarang, 5(3), 1-14.

Reedy, A., Pfitzner, D., Rook, L., \& Ellis, L. (2021). Responding to the COVID-19 emergency: student and academic staff perceptions of academic integrity in the transition to online exams at three Australian universities. 9, 1-32. https://doi.org/10.1007/s40979-021-00075-9.

Rustam, A., Sari, E.D.K, \& Yunita, L. (2018). Statistika \& Pengukuran pendidikan ( Analisis Menggunakan SPSS, Iteman dan Lisrel). Ilham Sejahtra Persada.

Sari, E.D.K. (2018). Implementasi Evaluasi Berbasis Hots (Higher Order Thinking Skill) Terhadap Peningkatan Kemampuan Penalaran Verbal Siswa Dalam Pembelajaran Pai Di Smpn 7 Bekasi. Almarhalah/ Jurnal Pendidikan Islam, 2(1), 39-50. http://journal.almarhalah.ac.id/index.php/almarhalah/article/view/16.

Sari, E.D.K. (2019). Pengembangan Instrumen Etika Profesi Guru Sekolah Dasar Negeri di Daerah Khusus Ibukota Jakarta Development of Professional Ethics Instrument in Public Elementary School Teachers in the Special Capital Region of Jakarta. Universitas Negeri Jakarta.

Sari, E.D.K, \& Falani, I. (2021). Developing Instrument to Measure Elementary School Teachers' Professional Ethics in Indonesia. Elementery Education Online, 20(2), 133-144. https://doi.org/10.17051/ilkonline.2021.02.14.

Sari, E.D.K, Huda, ade nailul, \& Muthahari, F. (2017). Penilaian Rubrik Dan Motivasi Belajar Terhadap Hasil Praktik Ibadah Shalat Di SDI Tahta Syajar Bekasi. Prosiding Seminar Nasional Pendidikan FKIP, $1(2)$. http://jurnal.untirta.ac.id/index.php/psnp/article/view/143-150.

Sari, E.D.K, \& Mahmudi, I. (2019). The Effect Of Authentic Assessment And Teaching Variation Toward Fiqih Learning Outcomes (An Experiment at Ponpes An Nida Al IslamyBekasi). 14(2), 14-25. https://ejournal.unida.gontor.ac.id/index.php/tadib/article/view/3256. 
Sari, E.D.K, Tolla, B., \& Margono, G. (2019). Validity Test Construction Measure EPG (Teacher Proffesional Ethich) "Personal Value Dimension." IJER - Indonesian Journal Of Educational Review,

$6(2)$. http://journal.unj.ac.id/unj/index.php/ijer/article/view/14074.

Sarjana, S., \& Khayati, N. (2017). Pengaruh Etika, Perilaku, Dan Kepribadian Terhadap Integritas Guru. Jurnal Pendidikan Dan Kebudayaan, 1(3), 379. https://doi.org/10.24832/jpnk.v1i3.450.

Scott, G. W. (2017). Active engagement with assessment and feedback can improve GroupWork outcomes and boost student confidence. Higher Education Pedagogies, 2(1), 1-13. https://doi.org/10.1080/23752696.2017.1307692.

Setiaji, B., Hayaty, M., Setyanto, A., Krisnawati, \& Santoso, H. B. (2021). Assessing User Experience of a Secure Mobile Exam Application using UEQ+. 246-251. https://doi.org/10.1109/icoiact50329.2020.9332091.

Sri, G., \& Nurmiati, N., Muliana, M., Sulaiman, O. K., Ginantra, N. L. W. S. R., Manuhutu, M. A., Sudarso, A., Leuwol, N. V., Apriza, A., \& Sahabuddin, A. A. (2020). Belajar Mandiri: Pembelajaran Daring di Tengah Pandemi Covid-19. Yayasan Kita Menulis.

Stoesz, B. M., Eaton, S. E., Miron, J., \& Thacker, E. J. (2019). Academic integrity and contract cheating policy analysis of colleges in Ontario, Canada. International Journal for Educational Integrity, 15(1). https://doi.org/10.1007/s40979-019-0042-4.

Sugiyono. (2012). Metode Penelitian Kuantitatif dan Kualitatif dan R\&D. Alfabeta.

Sugiyono. (2016). Statistika untuk penelitian. Alfabeta.

Vázquez Toledo, S., Latorre Cosculluela, C., Liesa Orús, M., \& Rivera-Torres, P. (2021). The Mutual Assessment System in Teamwork: The Value of the Individual Grade. Practical Assessment, Research, and Evaluation, 26(1), 3. https://scholarworks.umass.edu/pare/vol26/iss1/3/.

UNESCO. (2020). Exams and assessments in COVID-19 crisis: fairness at the centre. 2020. https://en.unesco.org/news/exams-and-assessments-covid-19-crisis-fairness-centre.

Vučković, D., Peković, S., Blečić, M., \& Đoković, R. (2020). Attitudes towards cheating behavior during assessing students'performance: student and teacher perspectives. International Journal for Educational Integrity, 16(1), 1-28. https://doi.org/10.1007/s40979-020-00065-3.

Wahyudi, W., Rufiana, I. S., \& Nurhidayah, D. A. (2020). Quizizz: Alternatif Penilaian di Masa Pandemi Covid-19. Jurnal IImiah Soulmath: Jurnal Edukasi Pendidikan Matematika, 8(2), 95. https://doi.org/10.25139/smj.v8i2.3062.

Wangid, M. N., Mustadi, A., Senen, A., \& Herianingtyas, N. L. R. (2017). The evaluation of authentic assessment implementation of Curriculum 2013 in Elementary School. Jurnal Penelitian Dan Evaluasi Pendidikan, 21(1), 104-115. https://doi.org/10.21831/pep.v21i1.15779.

Widyarini, I., Yuniarti, K. W., \& Nugraha, L. A. (2019). Kerangka Konseptual Integritas: Studi Eksplorasi pada Guru-guru Sekolah Dasar di Yogyakarta. Mediapsi, 5(1), 16-29. https://doi.org/10.21776/ub.mps.2019.005.01.2.

Yulk G.A \& Van Fleet, D. . (1992). "Theory and Research on Leadership in Organizations",. In Dunnette, M. D. dan Hough, L. M. (ed), Handbook of Industrial \& Organizational Psychology, (2nd ed., Vol. 3). Consulting Psychologists Press. 